\title{
Kant, Freedom as Independence, and Democracy
}

Rostbøll, Christian F.

Published in:

The Journal of Politics

DOI:

$10.1086 / 685448$

Publication date:

2016

Document version

Publisher's PDF, also known as Version of record

Citation for published version (APA):

Rostbøll, C. F. (2016). Kant, Freedom as Independence, and Democracy. The Journal of Politics, 78(3), 792805. https://doi.org/10.1086/685448 


\title{
Kant, Freedom as Independence, and Democracy
}

\author{
Christian F. Rostbøll, University of Copenhagen
}

While the influence of Kant's practical philosophy on contemporary political theory has been profound, it has its source in Kant's autonomy-based moral philosophy rather than in his freedom-based philosophy of Right. Kant scholars have increasingly turned their attention to Kant's Rechtslehre, but they have largely ignored its potential contribution to discussions of democracy. However, Kant's approach to political philosophy can supply unique insights to the latter. His notion that freedom and the public legal order are coconstitutive can be developed into a freedom argument for constitutional democracy. This freedom argument goes beyond freedom as moral autonomy and a libertarian idea of freedom as noninterference to a notion of freedom as a form of standing constituted by the public legal order. The trouble with other attempts to connect freedom and democracy is that they have operated with a moral ideal that is independent of a public legal order.

$\mathrm{T}$ he practical philosophy of Immanuel Kant has had a profound influence on contemporary political philosophy. However, it is only in the last few years that commentators have moved beyond Kant's autonomy-based moral philosophy to in-depth treatments of his freedombased political philosophy. Contemporary Kant scholarship suggests that Kant's philosophy of Right has a value of its own and that it should not be understood as a mere application of his moral philosophy (Pogge 2012; Ripstein 2009; Willaschek 2009; Wood 2002). Thus, there are theoretical resources in Kant's Rechtslehre, or the "Doctrine of Right" (the first part of The Metaphysics of Morals), and in his political essays that go beyond those found in his moral philosophy. Arthur Ripstein's Force and Freedom (2009) is an exemplary work that both demonstrates the uniqueness of Kant's legal and political philosophy and indicates how it can enlighten contemporary debates. However, Ripstein's work is also remarkable for its absence of a discussion of how Kant's political philosophy and his conception of freedom can contribute to the discussion of democracy.

My aim in this article is to establish that and show how Kant's approach to legal and political philosophy can supply a unique contribution to the discussion of democratic authority. At the core of Kant's political philosophy is the idea of the juridical state (der rechtliche Zustand) as a system of equal freedom. In the current literature, it has been emphasized how Kant regards a public legal order as constitutive of freedom as independence or of the equal standing of citizens in relation to one another. Legal and political institutions are not mere instruments "for securing a result that can be described independently of them" (Ripstein 2009, 218). I suggest that this Kantian insight can be extended to a discussion of democratic institutions and political rights: Democracy should not be regarded as a moral ideal that can be understood independently of legal and coercive institutions. From the perspective of Kant's philosophy of Right — as opposed to a purely ethical perspective - we must evaluate democracy as part of a public legal order or a constitutional system. Ripstein and others have focused on a public legal order as necessary for freedom, but I go further to consider why, from a Kantian perspective, democratic rights must be part of this legal order.

It is a fundamental Kantian idea that morality, including Recht, concerns "not what we should bring about, but how we should relate to one another" (Korsgaard 1996, 275). What is special about political and legal philosophy, from a Kantian perspective, is its focus on how formal institutions and law relate citizens to one another. This has implications for how we approach the question of the moral importance of democracy. Today it is common to ask about "the value of democracy," as if we were looking for some benefit that democracy affects. This is true of both instrumental and noninstrumental arguments for democracy. Some noninstrumental arguments even regard democracy as something citizens might enjoy or prefer (Anderson 2009). To the Kantian, this is the wrong way

Christian F. Rostbøll (cr@ifs.ku.dk) is a professor of political theory in the Department of Political Science, University of Copenhagen, 1353 Copenhagen K, Denmark.

The Journal of Politics, volume 78, number 3. Published online May 10, 2016. http://dx.doi.org/10.1086/685448

(C) 2016 by the Southern Political Science Association. All rights reserved. 0022-3816/2016/7803-0012\$10.00 
to assess political legitimacy. The Kantian is concerned about what might (or might not) make it obligatory to establish democratic rule, independently of our preferences for it. Selfavowed noninstrumental arguments for democracy tend to look for a value of democracy that is actually external to democracy, such as justice or equal treatment (Rostbøll 2015b). A Kantian noninstrumental account opens up the possibility of finding the moral importance of democracy in something that cannot be fully conceived independently of the idea of a democratically organized public legal order. Thus, the core Kantian contribution is to suggest that we should not look for how democracy realizes a value that can be conceived independently of democratic institutions; rather, we should consider whether and how a democratic public legal order constitutes something of moral importance.

Freedom as independence or the standing of not having another person as a master is what, ideally, is realized by a constitutional democracy. It might be thought that Kant's conception of external freedom (when properly distinguished from moral autonomy) is exactly a type of freedom that does not require democratic self-legislation and that does not lend itself to the type of noninstrumental argument for democracy that I propose. In addition, it might be objected that a Kantian could not see majority decision making as constitutive of freedom, because it makes the majority the master of the minority. However, these objections have a partial understanding of democracy and of what is required for seeing democratic rights as morally required. Insofar as Kant was in favor of voting rights and the majority principle at all, he clearly was so only as part of a constitutional system with representation, the separation of powers, and protection of individual rights. However, this does not mean that democratic rights are not morally important, but only that they should be seen as part of a larger constitutional system. For a Kantian it is the public legal order, as "a system of laws for a people" (MM, 6:311), which should be a system of equal freedom. This is exactly the virtue of the Kantian approach and not a vice. When we speak of the moral importance of democracy, there is no reason to speak of the value of unfettered collective self-legislation, direct democracy, or simple majoritarianism. This is not what modern democracy is, and this is not what we argue for when we attempt to give noninstrumental and/or freedom arguments for democracy. Thus, when I suggest that Kant can contribute to the discussion of the moral importance of democracy, I

1. References to Kant will be given with volume and page number of Kant's gesammelte Schriften (Kant 1900-). "MM" stands for The Metaphysics of Morals, "PP" stands for "Toward Perpetual Peace," and "TP" stands for "On the Common Saying: That May Be Correct in Theory, but It Is of No Use in Practice.” For translations, see Kant (1996a). mean the legitimacy of modern, constitutional, and representative democracy. To be clear, I speak of the latter in ideal terms and do not mean to imply that actual, existing democracies are systems of equal freedom. Indeed, actual democracies can and should be criticized from the perspective of the Kantian ideal.

I begin with a reconstruction of Kant's notion of freedom as independence, distinguishing it from moral autonomy and connecting it to positive law. This reconstruction is necessary for three reasons. First, many commentators still indiscriminately regard all Kantian arguments as autonomybased arguments, which is why we need to distinguish more clearly between Kant's approach to ethics and law. Second, explaining the internal relationship between freedom and law is critical for understanding why a Kantian would not ask about the external value of democracy and for developing his noninstrumental approach to law and politics. Third, many objections to "freedom arguments" for democracy still hold on to a libertarian idea of natural freedom or freedom as noninterference. From this point of view, it is impossible to show anything but an empirical relation between freedom and democracy (Berlin 1969, 129-31). Following the analysis of the internal connection between freedom and a public legal order, I discuss whether and why democratic rights and representation ought to be part of a constitutional system of equal freedom. In particular, I analyze Kant's thoughts on republicanism and representation. The last part of the article indicates how the Kantian approach to law and politics can contribute to a current discussion in democratic theory. I reveal how some of the hesitation to accept freedom arguments for democracy relies on a failure to consider the unique Kantian approach to freedom and authority.

\section{FREEDOM, NOT AUTONOMY}

Readers of Kant's moral philosophy will most likely associate a Kantian idea of freedom with the idea of giving laws to oneself (Kant 1996a, 4:433, 440). This notion of autonomy seems to connect directly to democracy, as an ideal of citizens being simultaneously authors and subjects of the law. However, the Kantian notion of moral autonomy is not workable as the basis of an account of political obligation, and we need the latter in our discussion of democratic authority. Political obligation concerns the state's moral right to rule and the citizens' obligation to obey the laws (Simmons 2002). The latter means that citizens must accept as valid and morally binding even laws with which they disagree. But a person cannot regard laws with which he or she disagrees as an expression of her moral autonomy, as Robert Paul Wolff (1998) demonstrated some time ago. This is part of the reason why we, in a discussion of democratic authority, which requires an account of political 
obligation and which realistically cannot depend on consensus on every law, should not rely on Kant's notion of moral autonomy, but need the notion of freedom as independence. We need a notion of freedom that is directly related to the legal form and coercion.

The Metaphysics of Morals begins with an important distinction between ethics and Right (Recht; MM, 6:213-14, 218-21); moral autonomy belongs to the former, freedom as independence to the latter. The core difference between ethics and Right, between internal freedom or autonomy and external freedom or freedom as independence, is that only the latter is internally connected to coercion. Indeed, in Kant, the authorization to use coercion is internal to the concept of Right and to external freedom (MM, 6:231). Moral autonomy requires that one act rightly for the sake of acting rightly. This is not a form of freedom that can be enforced, because this would entail that one acts rightly because one is forced to do so rather than doing it from duty. Being externally free in the sense of freedom as independence does not require any specific incentive (it does not require that one acts from duty), and because it concerns the external harmony between the choices of a plurality of persons, it is enforceable. Right and external freedom are social in a way moral autonomy is not and depend on external and positive coordination (Willaschek 2009, 64, 67). As such, coercion from the outset is not a threat to freedom as independence as it is to internal freedom or moral autonomy.

Note here that in giving oneself the moral law, one is immediately subject to it as an expression of one's own insight into what is right and wrong. The individual person can become morally autonomous by an act of internal willing. This way of realizing autonomy is not possible in politics that makes use of positive law. Jürgen Habermas $(1998,257)$ has suggested that "the positive character of law forces autonomy to split up in a peculiar way" and "makes it conceptually necessary to distinguish the role of authors who make (and adjudicate) law from that of addressees who are subject to established law." This split is a consequence of the fact that public law entails setting up a coercive authority, which enforces the law on subjects from the outside. Consequently, positive law cannot be seen as a form of internal willing on the part of the individual person. For Habermas, this implies a distinction in politics between private and public autonomy, while I suggest that we move entirely beyond an ideal of autonomy to the idea of freedom as independence. The positive character of law combined with the possibility of disagreement and the right to equal freedom that makes

2. I follow the convention among most English commentators of rendering the noun Recht, which can denote law, justice, and right, as "Right." disagreement morally salient force us to give up grounding political legitimacy in autonomy.

Freedom as independence stands at the core of Kant's legal and political philosophy. "Freedom (independence from being constrained by another's choice), insofar as it can coexist with the freedom of every other in accordance with a universal law, is the only original right belonging to every man by virtue of his humanity" (MM, 6:237). This only innate right of humanity is intimately connected to the Universal Principle of Right, the basic principle of Kant's Rechtslehre: "Any action is right if it can coexist with everyone's freedom in accordance with a universal law, or if on its maxim the freedom of choice of each can coexist with everyone's freedom in accordance with a universal law" (MM, 6:230). It is important to note that the Universal Principle of Right is not directed to the individual, in the same way that the categorical imperative of Kant's moral philosophy is, but is a principle for the right ordering of the public legal order (Pogge 2012, 82). We turn to Kant's philosophy of Right exactly to find principles for the state rather than for individual, moral action.

In the Rechtslehre, then, Kant understands freedom as a question of not having another person as a master. As such, it is an ideal of being one's own master, but it is essential not to confuse this ideal with a positive conception of freedom that sees freedom as a character ideal asserting the value of selfmastery (Berlin 1969, 131-34). The positive freedom ideal of self-mastery concerns the relation the person has to herself, while the ideal of not having another person as a master is an ideal for how persons should stand in relation to one another. This is part of what it means to say that freedom as independence is an external freedom rather than an internal freedom. Freedom as independence is not an ideal of internal willing, but an interpersonal notion of not being subordinate to other persons' choices. Not being subordinated to another person's choice means being able to use one's own powers for one's own purposes. The state respects citizens' freedom in this sense, as far as each is independent to follow and use her own powers of choice compatible with others' right to do the same. Citizens' independence is violated when others decide on their behalf what their purposes should be. Therefore, independence is not an ideal pertaining to the content of the lives citizens ought to live, but, rather, a principle designating the relation in which citizens should stand to one another. This clarification is important to note in order to avoid the objection to the sectarianism and paternalism of positive conceptions of freedom. Freedom as independence does not dictate a mandatory form of autonomous life that some people reasonably reject.

The idea that freedom as independence is a norm that regulates relations between a plurality of persons, rather 
than an ideal for the content of the lives of these persons, connects to another significant characteristic of this conception of freedom: It is a norm that must be respected rather than a good that should be promoted or maximized. Freedom as independence is a standing that cannot be seen as maximized or promoted, instrumentally, by a public legal order; rather, it is constituted by it. The standing of being one's own master does not depend on the goodwill of others but on legal rights and on a public legal order. This legal order or constitution must have a specific form in order to constitute a system of equal freedom. Before we get to the form of the legal order, however, we must understand why Kant thinks freedom is internally connected to positive law and a constitutional order in the first place.

\section{THE PUBLIC LEGAL ORDER AND FREEDOM}

A distinctive feature of Kant's notion of freedom as independence is its internal connection to a public legal order or a juridical state (rechtlicher Zustand). ${ }^{3}$ More specifically, the innate right to freedom is not a moral ideal specified independently of the idea of a plurality of persons living under a common, coercively enforced legal order. Legal institutions, therefore, cannot be seen as mere instruments to the realization of the right to freedom (Ripstein 2009, 9). I explain this point further in a moment, but I want first to mention that its internal connection to coercion and law seemingly makes it both easier and harder to connect freedom to democratic rule. It makes it easier because freedom as independence is not a notion of freedom that rejects all coercive rule, which would make it incompatible also with democratic rule from the outset. More precisely, the internal connection between freedom and rule opens up for noninstrumental arguments for democratic rule. However, the internal connection to coercion also distinguishes freedom as independence from Kant's own notion of moral autonomy, which might be thought to be more easily connected to a demand for democracy, because it is an ideal of self-legislation.

In Kant, then, the right to freedom cannot be defined independently of the idea of a plurality of persons living under a common, coercively enforced legal order. Freedom as independence concerns what it means to be free among a multitude of people whose choices and actions may obstruct one another. It is not possible to conceive of this freedom independently of the assurances given by a public legal order; that is, it is not possible to think freedom for a multitude

3. Kant's notion of the rechtlicher Zustand is the predecessor of the later idea of the Rechtsstaat, which in English can be translated as a state under the rule of law or a constitutional state (Byrd and Hruschka 2010, 25-28). I shall also use "public legal order." of persons in space without thinking the rule of law as a system of positively enforced individual rights. This insight of Kant's relies on the claim that a public legal order establishes a common will that through reciprocal coercion upholds universal laws of freedom. Only by submitting to a public legal order can a multitude of human beings whose choices inevitably affect one another avoid being dependent on the unilateral will of another.

Freedom as independence concerns the external freedom of agents whose actions may obstruct one another (MM, $6: 307,311)$. The right not to be constrained by the choice of another relates to the obstruction to one's own choices that others' choices may affect. The only way that my external freedom can be secure is if other persons' potential interference with my choices is obstructed. Because freedom as independence concerns external freedom and not incentives, it can be regulated by coercion; and because freedom as independence requires assurance and security of freedom, "as a hindering of a hindrance to freedom," it requires coercion (MM, 6:231).

However, it is not only my freedom that is to be protected but also the equal freedom of everyone. Kant never speaks of freedom as independence as a matter of not being obstructed in doing what one wants or as a general right against interference, but always as the right to freedom under reciprocally enforced and universal laws. "Right is the limitation of the freedom of each to the condition of its harmony with the freedom of everyone insofar as this is possible in accordance with a universal law" (TP, 8:290). The "principle of innate freedom already involves ... innate equality, that is, independence from being bound by others to more than one can in turn bind them; hence a human being's quality of being his own master (sui juris)" (MM, 6:237-38).

The reason why freedom as independence involves equality is that the issue is not the empirical likelihood of being secure against interference, but, rather, the normative or categorical one of not being dependent on some particular or private will for the ability to pursue one's ends. The only way to achieve this moral end is to set up a common will that reciprocally coerces everyone, and thus one's freedom is dependent on this will (the public legal order) rather than any private will. This also means that freedom as independence cannot be understood as a benefit I can enjoy on my own (as noninterference is); rather, freedom is a matter of how persons occupying the same space stand in relation to one another.

The public legal order, therefore, should not be seen or evaluated as something that bestows some independently identified benefit on the individual person. Rather, the constitution is something that relates citizens to one another in the 
normatively required way. Ideally, it relates citizens to one another as independent beings, that is, as persons with purposes of their own.

The public legal order, for Kant, is not merely a causal means to realize the right to freedom, but, rather, in a deep sense, constitutive of freedom as independence. This constitutiveness lies in the fact that general, public, and enforced laws bestow on citizens a standing in relation to one another. The rule of law neither assures the individual that she will not be interfered with (law will interfere with her actions if they are not compatible with the equal freedom of everyone) nor ensures that she will get what she wants (others may use their independence to take or compete for the same objects of desire); rather, it assures everyone a legal standing that means "that they may enjoy what is laid down as right" by a common will (MM, 6:311). To enjoy what is laid down as right by a common will means not being dependent on the will of another for realizing one's choices. You might say that one is dependent on the common will for getting what one wants. But a common will that establishes what is right, in Kant, does not have purposes of its own that one is forced to follow. Recht, as we have seen, can have no other aim than its intrinsic quality of securing the equal freedom of everyone. The Universal Principle of Right entails that freedom can be limited only for the sake of freedom. Thus, the standing of which the rule of law is constitutive is a standing of being a person whose freedom can be limited only for the sake of freedom.

The distinction between a private or unilateral will and a common, public, or omnilateral will plays a crucial role in Kant's notion of Right. It is not the number of persons sharing a will that determines whether it is a private or a common will, but, rather, how the will has been formed and what it wills. A private will lacks institutional form or procedures for its formation, and it has a particular end as its object. "The omnilateral will is different, because all that it provides is a form of choice, by providing procedures through which laws can be made, applied, and enforced" (Ripstein 2009, 196). Thus, the common will represents the public legal authority or the constitution (MM, 6:311). Dependence on a private will violates freedom because a private will has purposes of its own, while the dependence on a constitution is a precondition of freedom as independence, because it establishes "a collective general (common) and powerful will" (MM, 6:256) that harmonizes the free choices of each without having purposes of its own.

To grasp the uniqueness of the Kantian approach and its potential contribution to the issue of democratic authority, we should stress that the standing connoted by freedom as independence is not a matter of freedom as noninterference
(Berlin 1969, 122); nor can it be reduced to or identified with respect for equality. The standing connoted by freedom as independence cannot be understood in terms of freedom as noninterference, because coercion is itself constitutive of this standing. Freedom as independence refers to the security and assurance of independence of persons whose actions might affect one another, because they live side by side, and who can achieve independence only by the standing that coercive law affords them. To be sure, this standing does imply a form of respect for equality, but it is a specific form of respect for equality that is explained in terms of the norm of nondomination. Indeed, part of my argument is that we cannot fully understand the idea of respect for equality without an idea of free persons, and therefore an equality argument for democracy is incomplete without the freedom principle.

To understand further why law is not a mere means to freedom, note that positive law for Kant is not remedial or a response to our fallen condition, as in much natural law thinking. It is not because human beings are egoistic or fail to do what morality requires that law and coercion are necessary. "On the contrary, however well disposed and lawabiding human beings might be ... before a public lawful condition is established individual human beings . . can never be secure against violence from one another, since each has its own right to do what seems right and good to it and not to be dependent upon another's opinion about this" (MM, 6:312). The important point here is that law, in Kant, is not an unfortunate but necessary remedy or a limitation but, rather, an expression of freedom. Recht, as Ripstein $(2012,44)$ puts it, "is required because human beings are capable of setting and pursuing their own purposes. That capacity is not a limitation; it is our humanity itself."

The fact that there is a connection here between freedom as independence and respect for humanity does not mean that we collapse freedom as independence into moral autonomy. Kant (1996b, 6:26-28) defines humanity as the capacity of setting ends for oneself and not as the capacity to be morally self-legislating (Rostbøll 2011, 349-50). Thus, Recht and freedom as independence are connected to respect for the purposiveness of human beings but are independent of the idea of moral self-legislation. Kant's notion of Right as a coercive regulation of the external relations among citizens entails that, in politics, we cannot achieve autonomy as an ideal of internal willing.

While the Kantian argument is that rational beings can accept the rule of law as an expression of respect for their capacity to set ends for themselves, rather than as a mere means for maximizing their interests, respect for humanity should not be seen as a good we should expect the indi- 
vidual person to prefer. It is, rather, a norm rational beings cannot reject without contradicting their own rational nature. A rational agent can object to being forced for the sake of some end, but "a rational agent cannot object to being coerced for the sake of freedom itself. . . . A rational agent has nowhere to stand to reject it" (Hodgson 2010, 799). Thus, while freedom as independence is based on respect for humanity, this cannot be understood as a (sectarian) good; it is, rather, something we owe one another as rational beings.

By this, I do not mean to say that we as private persons owe it to each other to uphold relations of freedom as independence. Kant's point is exactly that such relations can exist only within a public legal order under a public will. However, Kant does think that individuals have an obligation to establish a state and that we "do wrong in the highest degree by willing to be and to remain in a condition that is not rightful" (MM, 6:307-8). Thus, it is a moral obligation to establish a public legal order under which alone everyone can have standing as free and independent beings.

The right to freedom, then, is grounded in a specific conception of the subject who is to be free. For Kant, it is grounded in the normative distinction between a person and a thing. A person is characterized by having purposes of her own, and the right to freedom is the right to be and live as a person. Without this idea of what a person is, it is difficult to make sense of the way in which Kant understands the right to freedom and why Recht is not a mere means to the satisfaction of interests. His whole "Doctrine of Right" builds on the idea that there is a difference between respecting someone as a purposive being and protecting or maximizing her interests.

In the negative freedom tradition, from Hobbes (1998, $139-40)$ to Berlin $(1969,122-23,128)$, freedom is a question of not being hindered in achieving one's goals or in satisfying one's desires; as such, it is an ideal of freedom as nonfrustration (Pettit 2012, 64-67). Freedom as independence cannot be understood in this way. The view that freedom concerns getting what one wants makes the extent of freedom dependent on what purposes one has, and Kant rejects that freedom depends on the content of one's purposes. Moreover, we are hindered by others in many ways in achieving our purposes, without our freedom for that reason being limited. Freedom as independence requires only that we not be subject to the choice of another (that we are not forced to pursue his purposes rather than our own), not that we are independent of the effects of the choices of others (Hodgson 2010, 810-12; Ripstein 2009, 33, 77). In addition, the standard understanding of negative freedom assumes that interference as such is inimical to freedom and that law limits freedom. But, as we have seen, the coerciveness of law is constitutive of freedom as independence. Freedom as independence is a matter neither of getting what one wants nor of minimizing coercion. Rather, it is about having a certain standing in relation to others. This standing requires the certainty, predictability, and reciprocity of law or Right as "that relation of human beings among one another that contains the conditions under which alone everyone is able to enjoy his rights" (MM, 6:305-6).

The preceding contrast to freedom as nonfrustration shows once again that freedom as independence is not about promoting some good from the perspective of the individual, be it nonfrustration or noninterference. Rather, the Kantian notion of external freedom designates a relation among persons. Notice that the idea that freedom as independence expresses a relation between persons is not the same as saying that "it limits the class of freedomrestricting obstacles to those created by other persons." Rather, it is to say that the question of freedom should not be approached from the perspective of the first-person singular, but from the shared perspective of "a multitude of human beings [who] affect one another" (MM, 6:311). This is a valuable idea for thinking about democratic legitimacy, insofar as the latter also should not be approached from what the individual from her own perspective can gain, but, rather, is a question of how a plurality of persons who inevitably affect one another ought to be related.

\section{REPUBLICANISM AND REPRESENTATION}

Until now, I have focused on the connection between external freedom on the one side and a public legal order on the other side. That is to say, in Kant we find an argument to the effect that a system of equal freedom can be neither fully conceived nor realized without the related idea and reality of a legal system with reciprocal coercion of external acts. This, however, does not yet bring us to an argument in favor of constitutional democracy. Thus, we must now note that Kant does not think that law and force are sufficient for freedom, which is clear, for example, in Anthropology from a Pragmatic Point of View, in which he writes that law and force without freedom are despotism (Kant 2007, 7:330-31). It is evident that in Kant, and we shall see this in the present section, the public legal order must have a specific form in order to combine law and coercion with freedom. My argument is that the issue of form is essential

4. Ian Carter $(2008,61-62)$ thinks that the latter makes freedom as noninterference a relational notion. 
for a Kantian approach to the understanding and justification of constitutional and representative democracy.

While Kant's views of external freedom, law, and coercion are well developed, his comments on different forms of government are relatively sparse. However, he does express some clear positions. ${ }^{5}$ The clearest position is in favor of republicanism, which for him is "the political principle of separation of the executive power (the government) from the legislative power" (PP, 8:352) and of both from the judiciary (MM, 6:316-17). A republic, Kant writes, is the only form of government "which makes freedom the principle and indeed the condition for any exercise of coercion" (MM, 6:340). This is the case because only republican government establishes public rather than personal authority, an omnilateral will rather than a unilateral will, or the rule of law rather than rule of (a) particular person(s). Thus, it turns out that the public legal order that we have discussed above in rather general terms must take the form of republican government.

What do republicanism and separation of powers have to do with democracy? According to Kant, "the form of government"-republic versus despotism, separation of powers versus no separation of powers-is more important than "the form of sovereignty," that is, who exercises sovereignty: one, the few, or the many (autocracy, aristocracy, or democracy; PP, 8:352; MM, 6:338-39). Moreover, for Kant, it is essential to distinguish a republic, a form of government, and democracy, a form of sovereignty. In Kant "democracy" refers to direct democracy, and he regards it as "necessarily" despotic, because when everyone is part of the sovereign, there can be no separation between those who give the rules and those who apply the rules (PP, $8: 352$ ). Insofar as we are interested in the meaning and authority of modern democracy, which is representative and constitutional, we need not worry too much about Kant's disparaging comments on democracy, which refers to direct democracy with no separation of powers. Indeed, I think that it is crucial to understand the uniqueness of constitutional and representative democracy and that Kant's Rechtslehre is a valuable resource in this regard.

The core issue for Kant is that the form of government is one that establishes a common will that differs from a merely private will. In order for the system of government to do this, it must be a constitutional system that provides legal procedures for the formation of a common will that

5. There are some differences between "Theory and Practice," "Perpetual Peace," and The Metaphysics of Morals regarding voting rights and preferred form of government (Byrd and Hruschka 2010, 175-79; Ludwig 2009). My concern is the final form of Kant's argument. goes beyond mere willing on behalf of a part of the population. The problem with direct democracy is that "it establishes an executive power in which all decide for and, if need be, against one (who thus does not agree), so that all, who are nevertheless not all, decide; and this is a contradiction of the general will with itself and with freedom" (PP, 8:852). The point here is not that the use of a majority principle is necessarily despotic - indeed, Kant proposes a majority principle as necessary in face of disagreement (TP, 8:296-97) - but that the use of majority decision as the sole principle and mechanism of government is so (Mulholland 1990, 325).

Equal freedom, then, is not secured by voting and majority rule alone but requires a constitution that establishes an impersonal public authority. This is required not because of the imperfect nature of men or of majorities but for categorical reasons. That is, only a constitutional system with separation of powers is designed for impersonal rule and respect for freedom as independence. Under direct democracy or simple majoritarianism, some (the minority) will be subject to the will of others (the majority). This is not the case in the republican system envisioned by Kant. Here everyone is subjected to a constitutional system. Citizens are dependent on this system and the common will that it establishes and not on the will of particular individuals, including the majority.

In order to establish an impersonal public authority, the government must be representative. "Any form of government which is not representative is, strictly speaking, without form" (PP, 8:352). A government with form is one with a constitution, which provides procedures for the formation of an omnilateral will. Kant's objection to direct democracy is exactly that it has no form and does not go beyond rule by a private or unilateral will. It lacks institutional procedures and standards for forming a will that all citizens can see as their common will, and it is thus "a contradiction of the general will with itself and with freedom" (PP, 8:852). As we have seen, freedom as independence cannot be understood independently of a common legal order. Insofar as direct democracy and simple majoritarianism are and can be realized independently of a public legal order or a constitutional system, they are without the form required by freedom as independence. The form required by freedom as independence is one in which the law speaks not only for some of the people but for the people as a collective body. This requires that we see law not as a product merely of the will of the majority but, rather, as a product of the constitutional system.

From a Kantian perspective, we should not ask about the value of, for example, voting or majority decision making 
independently of the constitutional system of which they are a part. What we should inquire into is the moral importance of the political-constitutional system in its entirety. Is this system one that expresses respect for the purposiveness and equal freedom of all citizens? What is required by such a system to realize equal freedom? In this way, we also avoid the misleading criticism of noninstrumental freedom arguments for democracy that (implicitly) assumes we are defending democracy without form or constitutional checks. ${ }^{6}$ This, too, is a reason to turn from Kant's autonomy-based moral philosophy to his freedombased political philosophy. Democracy as a purely moral ideal fails to connect to the procedural, institutional, and coercive aspects that are central for a Kantian legal and political philosophy the core of which is the external freedom of persons whose actions must be coordinated and who might disagree on how. Finally, focusing on constitutional and representative democracy has the advantage of relating to what we actually mean by "democracy" today.

\section{DEMOCRATIC REPRESENTATION}

I have argued that from the perspective of freedom as independence as the core norm of a public legal order, there are good reasons to embrace representation and separation of powers. What is not yet clear is why, from this perspective, representation has to be democratic; that is, why it has to include the opportunity for all adult citizens to vote and run for office, free, fair, and frequent elections, majority decisions, and the other aspects of representative democracy.

Kant writes, "The legislative authority can belong only to the united will of the people" (MM, 6:313). He explains this conclusion with the principle volenti non fit injuria (no wrong is done to someone who consents). He writes also that freedom is "the attribute of obeying no other law than that to which he has given his consent" (MM, 6:314). While these formulations suggest that consent does matter to Kant, we cannot derive an argument for democratic representation directly from them. That, I think, would lead us back to an autonomy model, which fails to take adequate account of how a system of equal freedom for a plurality of persons who affect one another depends on coercive law, which must be enforced also when unanimous consent cannot be secured. In addition, if the volenti principle and consent were the core of Kant's system, he would have only pragmatic reasons for advocating a representative system as opposed to direct democracy. But that is clearly not the case. Kant is giving a principled argument for representa-

6. See the section Freedom and Democracy below. tion, and that is what makes his thoughts unique and valuable for a discussion of modern democracy.

To advance the argument for democracy, we must return to the earlier point that freedom as independence is not a norm that can be fully conceived without the idea of a plurality of persons living under law. Ripstein rightly argues that Kant's approach to authority and validity of law is noninstrumental and nonepistemic. That is, the authority of the state or the legitimacy of the constitutional system is not based on its ability to produce correct results, as measured by some external epistemic standard. However, when it comes to the democratic ideal of collective self-legislation, Ripstein writes, "the idea that the people are the authors of the laws that bind them is thus a formal rather than material idea. ... Positive legislation is only legitimate if it could be a law that free persons could impose on themselves" (2009, 213; emphasis added). The latter is an epistemic standard that is external to the legal rights of citizens and actual procedures of decision making. It is a standard for what ought to be decided that says nothing about the actual procedures of decision making and of who should be included in them.

Discussing the same issue, Cristina Lafont (2012, 28085) argues that the validity of law in Kant is not a purely epistemic issue and that the actual consent required by the volenti principle confers independent validity on law and government. While my argument concurs in the point that in Kant we can find theoretical resources to show that the validity of law is not merely a matter of its substantive correctness but is inherently procedural and depends also on the possibility of expressing consent, I do not think we can explain this in the way suggested by Lafont. She argues that what explains majority rule and democratic inclusion in Kant is the volenti principle: Citizens do not need to consent to each law, but the volenti principle is satisfied because citizens have voluntarily consented to be bound by the collective decision made by the majority of citizens. In support of her interpretation, Lafont quotes "Theory and Practice"; but what Kant says in the quoted passage is that the principle of majority decision must be regarded "adopted as with [als mit] universal agreement and so by a contract, [and the latter] must be the ultimate basis on which a civil constitution is established" (TP, 8:296-97). Kant immediately adds that the original contract that establishes the constitution cannot be presupposed as a fact but is "only an idea of reason" (TP, 8:297). Textually, it is abundantly clear that Kant does not require that citizens voluntarily accept the constitution, and as a practical matter, constitutions and procedural issues are also objects of disagreement and thus cannot be said to be something to 
which citizens have given actual, unanimous consent, which is what Lafont's argument requires. Thus, she still operates within the autonomy logic. The argument from freedom as independence does not require, as do autonomy arguments, actual consent to the democratic procedures or to majority rule; the latter is not what explains why those who disagree with the correctness of the outcome must still regard it as legitimate in my argument. Rather, representative, constitutional government is justified because it is the only form of government that is designed to respect citizens' equal freedom, both as subject to law and as makers of law.

Yet, there are two important insights in Lafont's argument: that political legitimacy depends on the constitutional system as a whole and that consent has independent value. It is the constitutional system, as a system that designates procedures for lawmaking as well as the limits of law, that secures freedom rather than majority rule in and by itself. This is not because we have consented to the constitution but because the latter is constitutive of a system of equal freedom. Actual consent is important not for the justification of this system as a whole, but it is so as one element within the system. In other words, what gives the constitution authority is not consent, but part of the legitimacy of particular laws arises from the possibility of citizens to express consent through voting. Moreover, legitimacy of particular laws emanates not only from the consent through voting but also from the fact that the laws are made within a system that is designed to respect the equal freedom of all citizens.

While Kant was no supporter of universal suffrage, he did think voting as a form of consent was essential for being a citizen and for public Right (TP, 8:295; MM, 6:314-15). He writes that the government must represent the people "in order to protect its rights in its name, by all citizens united and acting through their delegates (deputies)" (MM, 6:341). Moreover, when he writes about republics being less likely to go to war (the famous democratic peace thesis), Kant clearly speaks of actual consent, of "when the consent of the citizens of a state is required" (PP, 8:350) and when citizens "must ... give their free assent, through their representatives" (MM, 6:345). If Kant did not think consent mattered, he would not have made voting part of being an active citizen and an essential element of public Right. There are good reasons to believe that Kant's principles support universal adult suffrage, while his own opposition to it was contingent and provisional (Maliks 2014, chap. 3; Weinrib 2008). Be that as it may, my concern is whether and why the Kantian approach to public Right and the core principle of freedom as independence require consent through voting, as an essential element in the constitutional system of equal freedom, if not as the legitimating principle of the system itself.
It might be said that the purposiveness of human beings cannot explain why the right to vote ought to be part of the constitution, since the purposiveness of human beings can be protected by civil rights alone. However, Kant's notion of freedom as independence is about more than the protection of the purposiveness of the individual seen in isolation from others. It is about the standing of a plurality of interconnected human beings in relation to one another. In addition, the denial of the right to vote for representatives is an affront to one's standing in the sense of freedom as independence. If one does not have the right to dismiss one's representatives in free elections and to express one's opinions and have them heard and included, one will be subject to others' choices and be "dependent on another's opinion about" what is "right and good" (MM, 6:312).

We should understand political and democratic rights in relation to the Kantian idea of a common will. For a will to be common, it must provide procedures of choice that secure that no one is dependent on the private will of another. But only if it is the procedures that determine who should decide and what should be decided could we say that everyone is dependent on these procedures rather than on some preprocedural or private will. Thus, it is only under democratic procedures where everyone has influence on who decides and what is decided through the vote and public judgment that the common will is truly procedural. If who decides is determined independently of or prior to actual procedures of decision making, which is the case in nondemocratic regimes, some will be dependent on the will of others rather than on shared procedures of decision making.

Still it might be asked, if one has the same rights to express one's opinions in a constitutional monarchy as in a democracy, wouldn't a subject in the former type of regime have the same standing as a member of the minority in a democracy who also does not make the decisions? No, clearly the standing of ordinary citizens in the two regimes is different. Even if you are allowed to exercise critical judgment in a constitutional monarchy, if your voice has no weight in decision making, your standing is not equal to those who make political decisions. In a representative democracy, the opinions and judgments of everyone are solicited not just in order that others can make more informed decisions on the behalf of everyone but also to determine whose opinion and judgment should prevail. The essential difference between democracy and nondemocratic regime forms is that only in the former does no one independently of the political process itself need to surrender to the will of another. Members who turn out to be in the minority in any given case must obey the decision of the majority in a democracy, but this does not mean that they are 
dependent on the will of another; it means only that their opinion failed to carry the day in a process in which no one is dependent on each other's choice. What everyone but the ruler(s) is subject to in nondemocratic regimes is a will that one can only hope to influence but never be part of, a will that one is dependent on no matter what happens in the political process. In a democracy, by contrast, one is subject only to a will everyone is equally free to form; the democratic will is not given independently of the political process. Because the voice of everyone in a democracy is counted, and always, in principle, could become part of the decision-making majority, no one must simply subject herself to another's opinion and choice. What Kant can help us to see in this connection is that our dependence is on the constitutional system rather than on any private will, and that the former system is one that ought to be designed to respect the equal freedom of everyone.

To summarize, the great value of Kant's philosophy of Right is that it leads us to asking how the constitutional system should be arranged in order to constitute a system of equal freedom. This system should not be evaluated on the basis of a result that is external to the system of rights and procedures of decision making of the constitutional system itself. Rather, the fundamental legitimacy of the system emanates from how it relates citizens to each other, the standing it affords them. It is readily apparent that Kant thinks the standing required by the right to freedom as independence depends on the rule of law. In this section, I have suggested that the constitutional system must include also core democratic institutions such as free elections and democratic representation. While my argument for democratic inclusion goes beyond the views of the historical Kant, there is some textual evidence for the notion that he thought representation through voting by citizens was an important element of public Right. More importantly, Kantian principles of equality and freedom as independence supply a unique explanation of the moral importance of democratic representation, an explanation that is based on what is required for the proper relation in which to stand to one's fellow citizens. The latter supplies a freedom argument for democracy that must be distinguished from an autonomy argument. A constitutional and representative democracy relates citizens to each other in a way that respects their freedom as independence even if it does not make them individually self-legislating.

\section{FORMALISM AND DEMOCRACY}

Given Kant's grand claim that Recht "proceeds entirely from the concept of freedom in the external relation of people to one another" (TP, 8:289; first emphasis added), his definition of freedom as independence might seem disappointingly indeterminate and even empty. Thus, it has been argued that the notion of freedom as independence fails to tell the legislator which forms of affecting others should be legally wrong and coercively prohibited as hindering a hindrance to freedom. "An independent (and necessarily controversial) account of persons' rights is needed to know what freedom as independence is.... Without such an account of what those rights are, the notion of freedom as independence is empty" (Valentini 2012, 454).

However, this objection misunderstands the purpose of Kant's theory. It is a mistake to look to freedom as independence as a foundation from which the legislator can derive a fully adequate scheme of rights, as Andrea Sangiovanni (2012) and Laura Valentini (2012) do in their critical comments on Ripstein's Kant. What Kant supplies is some few basic principles and an ideal account of the institutions required by them rather than a blueprint for what the legislator ought to decide. My suggestion in this section is that when it comes to establishing the connection between freedom and democratic rule, the formalism of the Kantian account turns out to be a virtue rather than a vice.

What Valentini and Sangiovanni are looking for is an account of what we might call outcome justice, that is, an account of which decisions the legislator ought to make. It is important, therefore, to emphasize the procedural and institutional nature of the Kantian argument. This type of argument does not tell us what justice concretely requires in the sense asked for by the quest for a full account of outcome justice. Rather, it tells us, first, about the need for establishing procedures and institutions that put everyone under reciprocal coercion and obligations. This requires a common as opposed to a unilateral will. Second, Kant's theory tells us how to approach questions of justice, namely, by focusing on the conditions of equal freedom rather than on contingent ends of happiness, security, welfare, and the like.

The quest for a full account of outcome justice overlooks that the normative work done by the right to freedom as independence is to explain the need for a state in which an indeterminate principle can be made determinate (Ripstein 2012, 489). If Kant presented a full and final theory of outcome justice that could explain exactly which system of rights to enact, and even how to apply it to particular cases, then the argument about the need for a common will and positive law that lays down what is right would be redundant. The core issue of procedural and institutional justice would be ignored, and only the need for enforcement would be left. However, if we overlook the importance for Kant of the procedures through which the justice of outcomes is determined, we fail to see the uniqueness of his approach to 
political philosophy and the contribution it can make to the question of democratic legitimacy.

A definitive theory of outcome justice that can tell us precisely what freedom requires, independently of the institutions that are needed to determine it, is perhaps exactly what we should avoid. An account of outcome justice that informs the legislator exactly about what to do would justify unilateral action in the name of freedom, but unilateral action is itself a violation of freedom as independence. In other words, the objection under consideration assumes that we can conceive freedom as independence separately from a common will and positive law, but it thereby fails to understand the importance of the latter for freedom itself. It is true that freedom as independence requires an account of rights, but it does not follow that this account must be given by an independently conceived theory of outcome justice, nor does it follow that freedom as independence is an empty notion. We should not confuse indeterminacy with emptiness.

Freedom as independence cannot be "filled out" by a procedure-independent account of outcome justice without contradicting the requirements of freedom as independence itself. Freedom as independence requires that what counts as Recht is determined by a common will of a particular society. Now, this interpretation should not lead us into thinking that whatever the sovereign decides is right. Kant does not espouse this kind of legal positivism (Höffe 2006, 82; Wood 2002, 6). Recht has normative elements; there are content constraints on what the sovereign can decide in order for its commands to be proper laws or Recht. In particular, the innate right to humanity requires that citizens' humanity is respected, that citizens are treated as persons with purposes of their own, and that they are secure in the enjoyment of what is their own, without "owing [this] ... to the choice of another among the people" (MM, 6:314).

The argument in this section indicates the need for institutions and procedures for determining the common will and, thus, opens up the possibility that democratic deliberation and decision making are required by respect for freedom. Indeed, because of its institutional and procedural character, the Kantian argument is more open to democratic deliberation about the requirements of freedom than is the quest for a prepolitical specification of freedom and rights.

\section{FREEDOM AND DEMOCRACY}

Above, I have reconstructed the Kantian approach to political authority and legitimacy in order to show its uniqueness. This section suggests that this approach can enhance contemporary debates in democratic theory regarding the via- bility of "freedom arguments" for democracy.7 I demonstrate the Kantian contribution by engaging arguments that are skeptical toward explaining democratic legitimacy with reference to freedom. In particular, I argue that those who reject freedom arguments for democracy have a too narrow understanding of what freedom arguments can be, by assuming that we must rely either on a conception of freedom as moral self-legislation or on a libertarian idea of freedom as noninterference. The common problem with both of these is that they disconnect the discussion of freedom and democracy from the idea of a public legal order and a constitutional system within which alone equal freedom is even conceivable.

The turn to Kant's philosophy of Right indicates how freedom arguments can be made independently of the idea of autonomy as an ideal of internal willing. It suggests also that, in asking about the rightness of political-legal institutions, we should not look to the external benefits that they effect from the perspective of the individual — be it welfare or the good of being individually self-governing. Rather, we should ask how human beings ought to be related to one another. Political and legal institutions constitute a specific relationship among persons that cannot be judged by some standard that is fully conceived independently of these institutions themselves. Most importantly, it is the public legal order that must express and respect the standing of each citizen as free in the sense of not having another person as a master. Freedom as independence neither is an ideal that is realized by limiting the reach of law through moral rights, as in libertarianism, nor is an ideal that is expressed by a moral ideal of collective self-legislation. Rather, freedom as independence is a more complex ideal that requires a form of government with different elements that together constitute a system of equal freedom. This form of government is a constitutional and representative democracy.

On this background, we can confront what is often thought to be the main obstacle to any attempt to make a freedom argument for democracy, namely, "the incompatibility problem" or the incompatibility between democracy and self-government. In the words of Allen Buchanan (2003, 17-18), "It is simply false to say that an individual who participates in a democratic decision-making process is selfgoverning; he or she is governed by the majority. ... An individual can be self-governing only if he or she dictates political decisions." Along similar lines, Thomas Christiano $(1996,25,24)$ writes, "Democracy is a system of decisionmaking where each is dependent on the assent or actions of

7. I discuss freedom arguments for democracy in Rostbøll (2015a, 2015b). The following draws on and reworks my earlier discussion. 
many others to secure what they want." This dependence is "a paradigmatic case of unfreedom." And Philippe Van Parijs notes, quoting Mill, that "individual freedom does not consist in the government of all by all, but in the 'government of each by himself'" (Van Parijs 1995, 17; cf. Mill 1989, 7-8).

From a Kantian perspective, there are four points to make about this objection. First, it assumes that freedom arguments for democracy are necessarily autonomy arguments. Second, the objection takes the perspective of the first-person singular rather than asking about how democracy relates citizens to one another. Third, it does not consider the possibility that freedom could be seen as internal to a public legal order. Fourth, it reduces democracy to the moment of majority decision making, implying that political decisions are necessarily made by a private will and ignoring the institutional and procedural nature of political will formation, as well as the Kantian distinction between person and office.

Freedom arguments for democracy, as well as Kantian political-theoretical arguments in general, are easily misunderstood as involving a strong view of autonomy. They are seen as implying either a sectarian idea of the autonomous life as the good life or a strong idea of collective autonomy in the sense that one can be free only if one is the author of the laws to which one is subject. By strictly relying on Kant's conception of freedom from the Rechtslehre, we can avoid both of these pitfalls. Since, in a Kantian approach, democracy is not justified with reference to the realization of some good for the individual, it is also not about realizing the good of autonomy for the individual. My claim, therefore, is that a Kantian approach to law and politics can show the moral importance of democracy in a way that does not require the strong interpretation of autonomy. Thus, even if Buchanan's objection has some merit when applied to a strong notion of autonomy, it does not apply to all freedom arguments for democracy.

When it is argued that democracy makes each person dependent on the rest and that this is a paradigmatic case of unfreedom, one takes the standpoint of a prelegal or preconstitutional situation and assumes that one can be free there. This is a libertarian view that takes for granted what Kant would call "wild, lawless freedom" (MM, 6:316). It is exactly the relevance of this understanding of freedom for public Right that Kant questions. If we begin with a notion of equal freedom the meaning of which is internal to coercion and law, we cannot say that it is democracy that makes us dependent on others. For a plurality of persons living side by side, it is their right to freedom that makes common laws necessary. The Kantian approach regards "the dependence of all upon a single common legislation" as a precondition of equal freedom (PP, 8:349-50). Our question should not be whether democracy can dissolve the dependence on reciprocal coercion but, rather, whether democratic decision making is an integral part of a public legal order that contains the conditions of equal freedom.

Critics of freedom arguments for democracy tend to assume that freedom is about getting what one wants. Kantian theory gives us good reasons to understand freedom different from the unhindered satisfaction of desires, the Hobbesian notion of freedom as nonfrustration mentioned above. Because freedom as independence is a relational notion, it does not concern what the individual can and cannot enjoy from her own, isolated perspective, but, rather, on the standing she has in relation to others. We see here the importance of the distinction between asking about the isolated value of democracy from the perspective of the first-person singular and asking about how democratic procedures contribute to the equal freedom of citizens who are dependent on a constitution for their freedom.

Buchanan's objection in effect regards democracy as nothing more than the act of the majority of the people imposing their private or unilateral will on the rest. In Kant, we find insights that can bring us beyond this view. According to Kant, establishing a public legal order entails rule by a common public will rather than by a private unilateral will. The common will is understood in procedural and institutional terms. It is the will not of a particular person but of an institutionally defined office or a public juridical authority. Moreover, the common will has a substantive element insofar as law, to be an expression of a common will, must be compatible with the right to equal freedom. Thus, the common will in Kant is not merely the will of a legally defined sovereign legislator or of the majority. To be a public and general will, it can have no purposes beyond its intrinsic quality of maintaining a rightful condition of equal freedom. The shortcoming of the Buchanan view is that it treats democracy as what Kant would call a "non-form" ("eine Unform," PP, 8:352), that is, a form of rule without a constitution (Pinzani 2008, 210). However, our question is not the legitimacy of direct and unconstitutional democracy, but of a more complex constitutional system that includes representation, separation of powers, and protection of fundamental rights.

Democracy as simple majoritarianism is inadequate, because it requires some to submit to the will of others in a way that fails to explain what makes this will a common will rather than a unilateral will. In order for democracy to be not only compatible with but also required by freedom as independence, the common will must be formed in a process that is designed to respect citizens' standing and continued 
independence. The idea that, in democracy, some (the minority) are dependent on the will or choice of others (the majority) is a consequence of an identification of democracy with a simple idea of majority rule. But if we see democracy as a constitutional form in the way Kant sees a republic and representative government, then we can go beyond the inadequate idea that democracy simply is majority rule and instead inquire into the place of democratic decision making within a constitutional system of equal freedom.

To say that democracy cannot be identified with simple majoritarianism does not mean that majority decision making should not play a prominent role in a democracy. Indeed, the right to vote and be counted equally in the formation of the decision-making majority is a necessary procedure in a constitutional system in which no one should be the master of another. Here, we must demonstrate that the use of the majority principle need not undermine freedom as independence. Note that the fact that you cannot get what you want through the political process is not a violation of freedom as independence if you have the equal right to participate in lawmaking as everyone else. As Philip Pettit (2012, 177-78) has argued, if the fact that a decision goes against you can be seen as tough luck, rather than as a result of a will that operated independently of the process in which you were an equal participant, then you are not dominated. This point is strengthened by my Kantian argument, according to which one's freedom is constituted by the standing afforded by the constitutional system and its decisionmaking procedures rather than by particular decisions. Of course, particular decisions can violate one's freedom as independence, but this is the case only if they violate the procedures of the constitution or violate the standing afforded by them.

What differentiates constitutional democracy from other constitutional forms of government is that it solicits the involvement and participation of every citizen in the opinion and will formation that result in the making of law. From a Kantian perspective, not only should a democratic constitution be designed to give everyone an equal opportunity to influence the decisions; it should also aim at decisions that are acceptable to everyone - government for the people, not just for the majority. When we follow democratic decisionmaking procedures, what is decided should not just be something that seems right and good to a portion of the population. Rather, political decisions should not be made until after the completion of a process in which everyone has been able to express, argue about, and vote for what seems right and good to each.

The understanding of democracy outlined here, to be sure, is a specific conception of democracy, and not every- one's conception of democracy. Indeed, it is a conception of democracy that follows from a commitment to the importance of relating citizens to one another in a way that respects their standing as free and independent beings with opinions of their own. Some might find it question begging in this way to tailor the definition of democracy to the norm that I argue requires democracy. But, as long as my definition of democracy is recognizable as a definition of democracy, the charge of circularity can be met. Also, my claim is not that actual constitutional democracies realize the ideal of freedom as independence, but only that this is what ideally justifies constitutional democracy. Insofar as actual democracies do not mirror this ideal, a Kantian would argue that they ought to be reformed in order better to do so.

\section{CONCLUSION}

Democracy is not an ideal that can be understood or assessed as a purely moral ideal, that is, independently of the idea and reality of a public legal order. Like civil freedom, democracy attains its meaning only as a constitutional ideal, that is, as an ideal for how a plurality of persons who live side by side should be related to one another by public, legal institutions. We fail to understand the authority of constitutional democracy if we see it merely as an instrument for realizing an ideal that can be conceived independently of constitutional rights and institutions, such as moral autonomy or a libertarian ideal of freedom as noninterference. These freedom ideals are not internally related to constitutional democracy. This, however, does not mean that all freedom arguments for democracy must fail. The value of Kant's philosophy of Right is exactly the way in which it demonstrates that freedom and the public legal order are coconstitutive. This article has sought to lay the foundation for developing this Kantian insight into a freedom argument for constitutional and representative democracy.

\section{ACKNOWLEDGMENTS}

I would like to thank Anders Berg-Sørensen, Enrico Biale, Emanuela Ceva, Charles Girard, Esben Høgh, Malte Frøslee Ibsen, Annabelle Lever, Reidar Maliks, Christiane Mossin, Valeria Ottonelli, Fabienne Peter, Troels Skadhauge, and Lars Tønder for comments on earlier versions of this article. I would also like to thank Lisa Ellis for editorial comments and my anonymous reviewers for their helpful feedback. Previous versions of this article were presented at the Geneva Colloquium in Political Theory, University of Geneva, Switzerland, April 10, 2014; workshop on "The Value of Democratic Procedures," University of Pavia, Italy, January 23-24, 2014; and Political Theory Seminars, 
University of Copenhagen, March 24, 2014. I wish to thank the organizers and participants.

\section{REFERENCES}

Anderson, Elizabeth. 2009. "Democracy: Instrumental vs. Noninstrumental Value." In Thomas Christiano and John Christman, eds., Contemporary Debates in Political Philosophy. Malden, MA: WileyBlackwell, 213-27.

Berlin, Isaiah. 1969. "Two Concepts of Liberty." In Four Essays on Liberty. Oxford: Oxford University Press, 118-72.

Buchanan, Allen. 2003. "Democracy and Secession." In Margaret Moore, ed., National Self-Determination and Secession. Oxford Scholarship Online. http://www.universitypressscholarship.com/view/10.1093/0198293844 .001.0001/acprof-9780198293842-chapter-2.

Byrd, B. Sharon, and Joachim Hruschka. 2010. Kant's Doctrine of Right: A Commentary. Cambridge: Cambridge University Press.

Carter, Ian. 2008. "How Are Power and Unfreedom Related?" In Cécile Laborde and John Maynor, eds., Republicanism and Political Theory. Oxford: Blackwell, 58-82.

Christiano, Thomas. 1996. The Rule of the Many: Fundamental Issues in Democratic Theory. Boulder, CO: Westview.

Habermas, Jürgen. 1998. "On the Internal Relation between Law and Democracy.” In Ciaran Cronin and Pablo De Greiff, eds., The Inclusion of the Other: Studies in Political Theory. Cambridge, MA: MIT Press, 253-64.

Hobbes, Thomas. 1998. Leviathan. Edited by J. C. A. Gaskin. Oxford: Oxford University Press.

Hodgson, Louis-Philippe. 2010. "Kant on the Right to Freedom: A Defense." Ethics 120 (July): 791-819.

Höffe, Otfried. 2006. Kant's Cosmopolitan Theory of Law and Peace. New York: Cambridge University Press.

Kant, Immanuel. 1900-. Kant's gesammelte Schriften. Edited by Royal Prussian (later German) Academy of Sciences. Berlin: Georg Reimer (later Walter de Gruyter).

Kant, Immanuel. 1996a. Practical Philosophy. Translated and edited by Mary J. Gregor. New York: Cambridge University Press.

Kant, Immanuel. 1996b. "Religion within the Boundaries of Mere Reason." In Allen W. Wood and George Di Giovanni, trans. and eds., Religion and Rational Theology. New York: Cambridge University Press.

Kant, Immanuel. 2007. "Anthropology from a Pragmatic Point of View." In Günther Zöller and Robert B. Louden, eds., Anthropology, History, and Education. New York: Cambridge University Press.

Korsgaard, Christine M. 1996. "The Reasons We Can Share." In Creating the Kingdom of Ends. Cambridge: Cambridge University Press, 275-310.

Lafont, Cristina. 2012. "Agreement and Consent in Kant and Habermas: Can Kantian Constructivism Be Fruitful for Democratic Theory?” Philosophical Forum 43 (3): 277-95.
Ludwig, Bernd. 2009. "Commentary on Kant's Treatment of Constitutional Right." In Karl Ameriks and Otfied Höffe, eds., Kant's Moral and Legal Philosophy. New York: Cambridge University Press, 265-83.

Maliks, Reidar. 2014. Kant's Politics in Context. Oxford: Oxford University Press.

Mill, John Stuart. 1989. On Liberty and Other Writings. Edited by Stefan Collini. Cambridge: Cambridge University Press.

Mulholland, Leslie A. 1990. Kant's System of Rights. New York: Columbia University Press.

Pettit, Philip. 2012. On the People's Terms: A Republican Theory and Model of Democracy. New York: Cambridge University Press.

Pinzani, Alessandro. 2008. "Representation in Kant's Political Theory." Jahrbuch für Recht und Ethik 16:203-26.

Pogge, Thomas W. 2012. "Is Kant's Rechtslehre a 'Comprehensive Liberalism'?” In Elisabeth Ellis, ed., Kant's Political Theory: Interpretations and Applications. University Park: Pennsylvania State University Press, 74-100.

Ripstein, Arthur. 2009. Force and Freedom: Kant's Legal and Political Philosophy. Cambridge, MA: Harvard University Press.

Ripstein, Arthur. 2012. "Form and Matter in Kantian Political Philosophy: A Reply." European Journal of Philosophy 20 (3): 487-96.

Rostbøll, Christian F. 2011. "Kantian Autonomy and Political Liberalism." Social Theory and Practice 37 (3): 341-64.

Rostbøll, Christian F. 2015a. "Non-domination and Democratic Legitimacy." Critical Review of International Social and Political Philosophy 18 (4): 424-39.

Rostbøll, Christian F. 2015b. "The Non-instrumental Value of Democracy: The Freedom Argument." Constellations 22 (2): 267-78.

Sangiovanni, Andrea. 2012. "Can the Innate Right to Freedom Alone Ground a System of Public and Private Rights?” European Journal of Philosophy 20 (3): 460-69.

Simmons, A. John. 2002. "Political Obligation and Authority." In Robert L. Simon, ed., The Blackwell Guide to Social and Political Philosophy. Oxford: Blackwell, 17-37.

Valentini, Laura. 2012. "Kant, Ripstein and the Circle of Freedom: A Critical Note." European Journal of Philosophy 20 (3): 450-59.

Van Parijs, Philippe. 1995. Real Freedom for All: What (If Anything) Can Justify Capitalism? Oxford: Oxford University Press.

Weinrib, Jacob. 2008. "Kant on Citizenship and Universal Independence." Australian Journal of Legal Philosophy 33:1-25.

Willaschek, Marcus. 2009. "Right and Coercion: Can Kant's Conception of Right Be Derived from His Moral Theory?" International Journal of Philosophical Studies 17 (1): 49-70.

Wolff, Robert Paul. 1998. In Defense of Anarchism. Berkeley: University of California Press.

Wood, Allen. 2002. "The Final Form of Kant's Practical Philosophy." In Mark Timmons, ed., Kant's Metaphysics of Morals: Interpretative Essays. New York: Oxford University Press, 1-21. 